\title{
DETECTION OF SUBCLINICAL MASTITIS IN MILK OF DAIRY COWS IN SOHAG CITY, EGYPT
}

\author{
NESREEN BAKR ${ }^{1}$; EMAN M. SHAKER ${ }^{2}$ and MOHAMMED SAYED ${ }^{3}$ \\ ${ }^{1}$ Maragha Veterinary Management, Sohag Directorate of Veterinary Medicine, Sohag, Egypt \\ ${ }^{2}$ Department of Food Hygiene, Faculty of Veterinary Medicine, Sohag University, Sohag, Egypt \\ ${ }^{3}$ Department of Food Hygiene, Faculty of Veterinary Medicine, Assiut University, Assiut, Egypt
}

Received: 30 December 2018; Accepted: 10 January 2019

\begin{abstract}
This study aimed to detect the incidence of subclinical mastitis (SCM) in the milk of dairy cows in Sohag city, Egypt. 100 quarter milk samples from all quarters of 25 dairy cows with apparently healthy udders were examined by strip cup test, California mastitis test (CMT), White side test (WST), chemical and bacteriological tests. From the obtained results, it was found that none of the strip cup test was positive, while CMT revealed $53 \%$ positive with various degrees, and the WST revealed $49 \%$ positive with various degrees. According the estimation of chloride $\%$ and lactose $\%$, the Koestler number was revealed $33 \%$ mastitic, $25 \%$ suspected and calculated $42 \%$ normal samples. According the bacteriological examination, out of the 39 bacterial isolates from the examined milk samples, Staph. aureus, Strept. agalactiae and E. coli were estimated 64.10\%, 28.21\% and $7.69 \%$, respectively.
\end{abstract}

Key words: Subclinical mastitis, CMT, WST, Koestler number

\section{INTRODUCTION}

Milk is one of the most important foods for human beings; it is universally recognized as a complete diet due to its essential components. In recent years, the demand for liquid milk is increased tremendously worldwide due to increased population growth (Klaas, 2000). However, milk production has been affected by various factors like mastitis (Payne and Wilson, 1999). Mastitis occurs throughout the world wherever dairy animals are found. Mastitis may be classified as clinical and subclinical. In contrast to visible changes in the acute form of mastitis, there is absence of visible abnormalities in the milk or udder in case of SCM. Most of the mastitis are subclinical in nature and their prevention depends primarily on good management practices of dairy herd which include stress-free environment, proper maintenance and operation of milking equipment, good milking procedures (Konwar et al., 2009).

SCM is of great economic importance to dairy farmers because it results in reduction in milk yield and undesirable changes in the milk's composition, as well as increased costs associated with control strategies (Halasa et al., 2009). Over one hundred

Corresponding author: EMAN M. SHAKER

E-mail address: milk_121970@yahoo.com

Present address: Department of Food Hygiene, Faculty of

Veterinary Medicine, Sohag University, Sohag, Egypt different microorganisms have been isolated from bovine mastitis, but the most frequently isolated microorganisms are Staphylococci, Streptococci and Gram-negative bacteria (Oliver et al., 2004; Hussain et al., 2012; Hussain et al., 2013). Staphylococci are considered as one of the main etiological agents of sub clinical mastitis in dairy cows (Unal and Yildirim, 2010).

There were several methods have been used for detection of SCM including physical and chemical changes of milk and isolation of associated organisms which is considered the most accurate although, it is expensive and time-consuming (Badiuzzaman et al., 2015). Therefore, sensitive, simple, rapid and reliable tests are required to be applied on a large scale of animals, (Radostitis et al., 2007); among these tests, CMT and WST (Greiner et al., 2000).

The present study aimed to detect the SCM in the milk of dairy cows located in Sohag city, Egypt, and to detect some of the pathogens causing SCM.

\section{MATERIALS AND METHODS}

The samples:

One hundred quarter milk samples were collected aseptically from all quarters of 25 dairy cows with apparently healthy udders in Sohag city, Egypt, according to the procedure recommended by Quinn et al. (2002). The collected samples were kept in an ice 
box and transported to the laboratory without delay where they were chemically and bacteriologically examined.

\section{Preparation of the samples (APHA, 1992):}

Each sample was divided aseptically into 2 portions; the $1^{\text {st }}$ one was used for chemical examination, while the $2^{\text {nd }}$ one was used for bacteriological examination.

\section{Examination of the samples: \\ I- Field tests: \\ 1) Strip cup test (Thirapatsakun, 1999):}

First few streams of milk were taken onto a strip plate. Mastitic milk will show discoloration, clots, or other abnormalities.

\section{2) California mastitis test (CMT) (Saloniemi, 1995):}

A plastic vessel with four shallow wells was used for collecting approximately $2 \mathrm{ml}$ of milk from each udder quarter; then equal amount of alkali reagent (Schalm reagent) was added. A gentle circular motion was applied to the mixtures in horizontal plane for 5 seconds and the different degrees of gel were recorded.

3) White side test (WST) (Schalm et al., 1971; Klastrup and Schmidt, 1974):

Five drops of milk were added to 2 drops of $\mathrm{NaOH}$ $4 \%$ on clean glass plate placed on dark black ground and mixed well and the reaction was graded according to the Scandinavian recommendations.

\section{II- Chemical examination:}

1) Chloride\% (Sanders, 1939):

In a beaker, $10 \mathrm{ml}$ milk sample, $5 \mathrm{ml}$ nitric acid $25 \%$ freshly prepared (act as catalyst), $5 \mathrm{ml}$ silver nitrate $\mathrm{N} / 10$ (combined with all chloride) and $1 \mathrm{ml}$ saturated iron alum solution (act as indicator) were added \& thoroughly mixed by glass rod. Titration was done against ammonium thiocyanate N/10 until brownish color was obtained and remained for 1.5-2 minutes (end point).

\section{2) Lactose\%:}

All the milk samples were examined for lactose $\%$ using Lactoscan milk analyzer (Ultrasonic portable milk analyzer, LSSP001, Bulgaria), in the laboratory of Milk Hygiene, Department of Food Hygiene, Faculty of Veterinary Medicine, Assiut University, Assiut, Egypt.

\section{3) Koestler number (Koestler, 1920):}

Koestler number $=\frac{\text { chloride }}{\text { lactose }} \times 100$

It is usually in normal milk less than 2 , in suspected milk from 2 to 3 , and in mastitic milk more than 3 .

\section{III- Bacteriological Examination:}

All the milk samples that showed positive results with field and chemical tests were subjected to bacteriological examination.

\section{1) Isolation and identification of Staph aureus:}

Enrichment procedure was done according to Bailey and Scott (1974) as the milk sample was inoculated into $\mathrm{NaCl}$ broth $10 \%$ and then incubated at $37^{\circ} \mathrm{C}$ for $24 \mathrm{~h}$, then loopfuls from the incubated broth were streaked (AOAC, 2000) on mannitol salt agar plates and then incubated for $24 \mathrm{~h}$ at $37^{\circ} \mathrm{C}$. Suspected colonies were picked up onto nutrient agar slants for further identification using anaerobic utilization of mannitol (Baird- Parker, 1962) and coagulase test (Cruickshank et al., 1973).

\section{2) Detection of Streptococcus agalactiae:}

By the using Hotis test (Hotis and Miller, 1936), 9.5 $\mathrm{ml}$ milk and $0.5 \mathrm{ml}$ of sterile aqueous solution of bromocresol purple $0.5 \%$ were mixed thoroughly (purple color appeared, $\mathrm{pH}$ 6.5) and incubated at $37^{\circ}$ $\mathrm{C}$ for $24 \mathrm{~h}$; the positive result was indicated by appearance of yellow color and flakes of canary yellow color at the side of test tube and if negative further incubation for $24 \mathrm{~h}$ was applied. A loopful from the positive tubes was inoculated into a slope agar for further examination using hippurate hydrolysis (Mahon and Manuselis, 1995).

\section{3) Coliforms count (MPN/g) (AOAC, 1975):}

$1 \mathrm{ml}$ of each 1:10, 1:100 and 1:1000 of the milk sample dilutions was inoculated into 3 replicate tubes of lauryl sulphate tryptose (LST) broth supplied with inverted Durham's tubes, and incubated at $35^{\circ} \mathrm{C}$ for $48 \mathrm{~h}$. Tubes showed gas in Durham's tubes within 48 $\mathrm{h}$ were submitted for confirmatory test. A loopful was inoculated into brilliant green lactose bile (BGLB) broth tubes with inverted Durham's tube and incubated at $37^{\circ} \mathrm{C}$ for $48 \mathrm{~h}$, and that showed gas in the Durham's tubes was recorded and considered positive for coliforms. The number of coliforms/g was calculated from the most probable number (MPN) table for 3 tubes dilution.

4) Fecal coliforms count (MPN/g) (AOAC, 1975): From all the positive BGLB broth tubes, a loopful was inoculated into Escherichia coli broth (EC broth) tubes with inverted Durham's tubes and incubated at $45.5 \pm 0.5^{\circ} \mathrm{C}$ for $48 \mathrm{~h}$. Tubes showed gas production in Durham's tubes were recorded and considered positive for fecal coliforms. The number of fecal coliforms $/ \mathrm{ml}$ was calculated using MPN table for 3 tubes dilutions.

\section{5) $E$. coli count (MPN/g) (AOAC, 1975):}

The positive EC broth tubes were subcultured by streaking on Eosin Methylene Blue (EMB) agar plates and incubated at $37^{\circ} \mathrm{C}$ for $48 \mathrm{~h}$. The typical nucleated dark center colonies with metallic sheen were considered to be $E$. coli positive. 


\section{RESULTS}

Table 1: The prevalence of SCM at udder-quarter level

\begin{tabular}{|c|c|c|c|c|c|c|c|c|c|}
\hline \multirow{2}{*}{\multicolumn{2}{|c|}{ No. of the infected animals }} & \multirow{2}{*}{\multicolumn{2}{|c|}{$\begin{array}{c}\text { No. of the infected } \\
\text { quarters }\end{array}$}} & \multicolumn{2}{|c|}{ Strip cup test } & \multicolumn{2}{|c|}{ CMT } & \multicolumn{2}{|c|}{ WST } \\
\hline & & & & \multicolumn{2}{|c|}{+ ve } & \multicolumn{2}{|c|}{$+\mathrm{ve}$} & \multicolumn{2}{|c|}{$+\mathrm{ve}$} \\
\hline No./25 & $\%$ & No./100 & $\%$ & No. & $\%$ & No. & $\%$ & No. & $\%$ \\
\hline 21 & 84 & 58 & 58 & 0 & 0 & 53 & 53 & 49 & 49 \\
\hline
\end{tabular}

Table 2: Statistical analytical results of CMT in the examined samples

\begin{tabular}{|c|c|c|c|c|c|c|c|c|c|c|c|c|c|}
\hline \multirow{3}{*}{$\begin{array}{l}\text { The } \\
\text { examined } \\
\text { quarter }\end{array}$} & \multirow{3}{*}{$\begin{array}{c}\text { The } \\
\text { quarter } \\
\text { No. }\end{array}$} & \multirow{2}{*}{\multicolumn{2}{|c|}{-ve CMT }} & \multirow{2}{*}{\multicolumn{2}{|c|}{ +ve CMT }} & \multicolumn{8}{|c|}{ +ve CMT samples scores } \\
\hline & & & & & & \multicolumn{2}{|c|}{ Score \pm} & \multicolumn{2}{|c|}{ Score +} & \multicolumn{2}{|c|}{ Score ++} & \multicolumn{2}{|c|}{ Score +++} \\
\hline & & No. & $\%$ & No. & $\%$ & No. & $\%$ & No. & $\%$ & No. & $\%$ & No. & $\%$ \\
\hline FL & 25 & 15 & 60 & 10 & 40 & 1 & 10 & 6 & 60 & 1 & 10 & 2 & 20 \\
\hline FR & 25 & 12 & 48 & 13 & 52 & 3 & 23.08 & 5 & 38.46 & 4 & 30.77 & 1 & 7.69 \\
\hline HL & 25 & 10 & 40 & 15 & 60 & 2 & 13.33 & 10 & 66.67 & 3 & 20 & 0 & 0 \\
\hline HR & 25 & 10 & 40 & 15 & 60 & 0 & 0 & 8 & 53.33 & 5 & 33.33 & 2 & 13.33 \\
\hline Total & 100 & 47 & 47 & 53 & 53 & 6 & 11.32 & 29 & 54.72 & 13 & 24.53 & 5 & 9.43 \\
\hline
\end{tabular}

$\mathrm{FL}=$ fore left quarter, $\mathrm{FR}=$ fore right quarter, $\mathrm{HL}=$ hind left quarter, $\mathrm{HR}=$ hind right quarter

Table 3: Statistical analytical results of WST in the examined samples

\begin{tabular}{|c|c|c|c|c|c|c|c|c|c|c|c|}
\hline \multirow{3}{*}{ The examined quarter } & \multirow{3}{*}{$\begin{array}{c}\text { The quarter } \\
\text { No. }\end{array}$} & \multirow{2}{*}{\multicolumn{2}{|c|}{$\begin{array}{c}- \text { ve } \\
\text { WST }\end{array}$}} & \multirow{2}{*}{\multicolumn{2}{|c|}{$\begin{array}{l}\text { +ve } \\
\text { WST }\end{array}$}} & \multicolumn{6}{|c|}{ +ve WST samples scores } \\
\hline & & & & & & \multicolumn{2}{|c|}{ Score + } & \multicolumn{2}{|c|}{ Score ++} & \multicolumn{2}{|c|}{ Score +++} \\
\hline & & No. & $\%$ & No. & $\%$ & No. & $\%$ & No. & $\%$ & No. & $\%$ \\
\hline FL & 25 & 17 & 68 & 8 & 32 & 6 & 75 & 1 & 12.5 & 1 & 12.5 \\
\hline FR & 25 & 12 & 48 & 13 & 52 & 7 & 53.85 & 5 & 38.46 & 1 & 7.69 \\
\hline HL & 25 & 12 & 48 & 13 & 52 & 12 & 92.31 & 1 & 7.69 & 0 & 0 \\
\hline HR & 25 & 10 & 40 & 15 & 60 & 11 & 73.33 & 4 & 26.67 & 0 & 0 \\
\hline Total & 100 & 51 & 51 & 49 & 49 & 36 & 73.47 & 11 & 22.45 & 2 & 4.08 \\
\hline
\end{tabular}

$\mathrm{FL}=$ fore left quarter, $\mathrm{FR}=$ fore right quarter, $\mathrm{HL}=$ hind left quarter, $\mathrm{HR}=$ hind right quarter

Table 4: Koestler number of the examined quarter milk samples

\begin{tabular}{cccccc}
\hline \multirow{2}{*}{ Parameter } & \multicolumn{2}{c}{ Quarter\% } & \multicolumn{3}{c}{ Koestler number } \\
\cline { 2 - 5 } & Normal & $\begin{array}{c}\text { SCM } \\
\text { affected }\end{array}$ & $\begin{array}{c}\text { Normal quarter\% } \\
(<2)\end{array}$ & $\begin{array}{c}\text { Suspected quarter\% } \\
(2-3)\end{array}$ & $\begin{array}{c}\text { Abnormal quarter\% } \\
(>3)\end{array}$ \\
\hline Chloride\% & $42 \%$ & $58 \%$ & \multirow{2}{*}{$42 \%$} & $25 \%$ & $33 \%$ \\
\hline Lactose\% & $42 \%$ & $58 \%$ & & & 3 \\
\hline
\end{tabular}


Table 5: Frequency of the affected quarters in relation to the all affected quarters (58)

\begin{tabular}{ccc}
\hline Quarter samples & Numbers affected & $\%$ \\
\hline FL & 11 & 18.96 \\
\hline FR & 15 & 25.86 \\
\hline HL & 16 & 27.59 \\
\hline HR & 16 & 27.59 \\
\hline Total & 58 & 100 \\
\hline
\end{tabular}

$\mathrm{FL}=$ fore left quarter, $\mathrm{FR}=$ fore right quarter, $\mathrm{HL}=$ hind left quarter, $\mathrm{HR}=$ hind right quarter

Table 6: Frequency of causative microorganisms in affected quarters in relation to total isolates (39)

\begin{tabular}{|c|c|c|c|c|}
\hline \multirow{2}{*}{$\begin{array}{l}\text { Type of the isolated } \\
\text { microorganisms }\end{array}$} & \multicolumn{2}{|c|}{ Number of the isolates } & \multicolumn{2}{|r|}{ Type of the quarter infection } \\
\hline & No. & $\%$ & single & Mixed \\
\hline Staph. aureus & 25 & 64.10 & 20 & $\begin{array}{l}\text { (4) Staph. aureus + Strept. agalactiae } \\
\text { (1) Staph. aureus }+ \text { E. coli }\end{array}$ \\
\hline Strept. agalactiae & 11 & 28.21 & 6 & $\begin{array}{l}\text { (4) Strept. agalactiae }+ \text { Staph. aureus } \\
\text { (1) Strept. agalactiae }+ \text { E. coli }\end{array}$ \\
\hline E. coli & 3 & 7.69 & 1 & $\begin{array}{l}\text { (1) Staph. aureus }+ \text { E. coli } \\
\text { (1) Strept. agalactiae }+ \text { E. coli }\end{array}$ \\
\hline Total & 39 & 100 & 27 & \\
\hline
\end{tabular}

Table 7: Number of the quarter milk samples in relation to coliforms counts

\begin{tabular}{cccc}
\hline Count/g. & $\begin{array}{c}\text { No. of the quarter } \\
\text { showed coliforms }\end{array}$ & $\begin{array}{c}\text { No. of the quarter showed } \\
\text { fecal coliforms }\end{array}$ & $\begin{array}{c}\text { No. of the quarter showed } \\
\text { E. coli }\end{array}$ \\
\hline$<3$ & 52 & 55 & 55 \\
\hline $3-<10$ & 2 & 1 & 1 \\
\hline $10-100$ & 2 & 1 & 0 \\
\hline$>100-1000$ & 1 & 0 & 1 \\
\hline$>1000$ & 1 & 58 & 58 \\
\hline
\end{tabular}

\section{DISCUSSION}

As shown in Table 1, it was found that the rate of SCM among the examined dairy cows revealed an incidence rate of $84 \%$ at the cow level. Nearly similar result was obtained by Duguma et al. (2014) and lower results were obtained by Ayano et al. (2013); El- Kholy et al. (2018). The rate of positive SCM in the examined milk samples revealed an incidence of $53 \%$ depending on +ve CMT at the quarter level. Nearly similar results of SCM using CMT were reported by Wahba et al. (2005); Enany et al. (2007); Mureithi and Njuguna (2016). Lower results were reported by Tanwar et al. (2001); Al-Hawary et al. (2003); Hussein (2012); Saidi et al. (2013); Barua et al. (2014); Sanotharan et al. (2016). Higher results were recorded by Kasikci et al. (2012); Kamal et al. (2014). The increased incidence of SCM among dairy animal may be attributed mainly to poor hygiene practices, inadequate housing \& bedding, malfunctioning milking machines, improper milking procedures and inadequate treatment methods. Treatment failures of SCM are common and may be due to delayed treatment, poor selection of drugs \& dose level, stopping treatment too soon, resistance of invasive organisms or deep seated infections that are protected by scar tissues (Philpot, 1984). 
CMT principle is based upon the amount of cellular nuclear protein in the milk sample, thus correlated to SCC (Greiner et al., 2000). CMT possesses many advantages, as the higher sensitivity, simplicity and accuracy; in addition, presence of foreign material, such as hair or other matter, does not interfere with the test.

The percentage of SCM among different quarters in the present study (Table 2) revealed that +ve CMT\% samples were $40 \%$ in fore left, $52 \%$ in fore right, $60 \%$ in hind left and $60 \%$ in hind right quarters. The higher prevalence of infection in the hind quarters may be due, in part, to the morphological structure of the udder (Donagh and William, 2005). It may also be attributable to the greater milk yield produced by the hind quarters (Lancelot et al., 1997).

As shown in Tables $1 \& 3$, it was found that the rate of SCM among milk samples by WST revealed an incidence rate of $49 \%$ at the quarter level. Nearly similar results of SCM by +ve WST were obtained by Shahid et al. (2011); Kabir et al. (2017); while lower incidences were obtained by Iqbal et al. (2004); Zahid (2004); Barua et al. (2014).

The obtained results in Table 3 showed +ve WST was in 2 quarters $(4.08 \%)$ with degree,+++ 11 ones $(22.45 \%)$ with degree,++ 36 ones $(73.47 \%)$ with degree + . The percentage of SCM among different quarters in the present study revealed that incidence of SCM in the hind quarters was higher than fore quarters.

Table 4 summarized the lactose $\%$ in relation to the percentages of normal and affected quarters; nearly similar result was reported by Swami et al. (2017). As the concentration of lactose decreased, compensation must be made to ensure that milk and blood maintain the same osmotic pressure. Most of this compensation is accomplished by increase of sodium and chlorides (Schalm, 1977). Ductal and secretory epithelium malfunction due to microbial infection leads to sharp increase of sodium and chlorine, in addition to break down of junctions between secretory cells, and the increased permeability of the blood capillaries. Thus, chlorine flowed into milk (Batavani et al., 2007). This explains the possibility of adopting chlorine\% in milk as an indicator for presence of SCM (Morsi et al., 2000), however, chlorine\% alone cannot judge the presence of mastitis as it usually give high results in colostrum or at late stage of lactation. Chloride\% in the present study was different from that obtained by Bhoyar et al. (2010); and nearly similar to that reported by Kamal et al. (2014); Gupta et al. (2017).

Owing to the fact that chloride and lactose $\%$ in milk account for approximately $75 \%$ of its osmotic pressure, many attempts have been made to establish the correlation between them on a complementary basis; among these attempts was those of Koestler
(El-Sokkary and Hassan, 1950). The obtained results of Koestler number were listed in Table 4 as $42 \%$ of the quarter's milk samples as normal, $25 \%$ of the quarter's milk samples as suspected and $33 \%$ of the quarter's milk samples as mastitic. The listed results (Table 4) declared that all the positive milk samples to CMT and WST had Koestler number ranged from 2 to 3 as suspected or more than 3 as mastitic.

According to the mentioned results in Table 5, the incidence of SCM in the examined milk samples according to the affected quarters were 11 (18.96\%) for FL, 15 (25.86\%) for FR, 16 (27.59\%) for HL and $16(27.59 \%)$ for HR.

When focusing the light on the bacteriological examination listed in Table 6, it was found that a total of 39 bacterial isolates were identified as Staph. aureus (64.10\%), Strept. agalactiae (28.21\%) and E. coli $(7.69 \%)$. The problem of these microorganisms not only economic or disturb animal health but also, produce a public health hazard to the human being.

It was concluded that there was a high incidence of SCM in the dairy cows located in Sohag city; and CMT \& WST findings represented valuable diagnostic methods in detection of cows with secretion disorders that showed no clinical signs of mastitis.

\section{REFERENCES}

Al-Hawary, I.I.; Sobeih, AzzaGG, M.K. and Aman, I. (2003): Further studies on the prevalence of subclinical mastitis in dairy cows in ElGharbia and Kafr El-Sheikh Governorate, Egypt with special observation to antibiotic sensitivity. Kafr El-Sheikh Vet. Med. J. 1(1): 331-343.

AOAC (1975): Association of Official Analytical Chemists. Official Methods of Analysis. 12 ed. P.O. Box 540, Benjamin Franklin station Washington.

AOAC (2000): Official Methods of Analysis, Food Composition, additives and contamination 7th Ed., Vol. 3 Public Association of Official Analytical Chemists, North Frederick Avenue, Gaithersburg, Maryland, USA.

APHA (1992): American Public Health Association, Standard method for the examination of dairy products. $16^{\text {th }}$ Ed., New York.

Ayano, A.A.; Hiriko, F.; Simyalew, A.M. and Yohannes, A. (2013): Prevalence of subclinical mastitis in lactating cows in selected commercial dairy farms of Holeta district. J. Vet. Med. Anim. Health. 5(3): 67-72.

Badiuzzaman, M.; Samad, M.A.; Siddiki, S.H.M.F.; Islam, M.T. and Saha, S. (2015): Subclinical mastitis in lactating cows: comparison of four screening tests and effect of animal factors on its occurrence. Bangladesh Journal of 
Veterinary Medicine, 2: 41-50. http://dx.doi.org/10.3329/bjvm.v13i2.26627.

Bailey, W.R. and Scott, E.G. (1974): Diagnostic Microbiology, $4^{\text {th }}$ ed. ST. Louis: C.V. Mosby Company.

Baird-Parker, A.C. (1962): An improved diagnostic and selective medium for isolation of coagulase positive Staphylococci. J. Appl. Bacteriol. 25: 12-19.

Barua, M.; Prodhan, M.A.; Islam, K.; Chowdhury, S.; Hasanuzzaman, Md.; Imtiaz, M.A. and Das, G.B. (2014): Sub-clinical mastitis prevalent in dairy cows in Chittagong district of Bangladesh: detection by different screening tests. Veterinary World, (7): 483-488.

Batavani, R.A.; Asri, S. and Naebzadeh, H. (2007): The effect of subclinical mastitis on milk composition in dairy cows. Iranian Journal of Veterinary Research, 8(3): 205-211.

Bhoyar, A.R.; Shende, C.V.; Nalawade, N.A. and Salunkhe, M.S. (2010): Mineral status of normal and subclinical mastitic milk of crossbred cow. Res. J. Animal Hus. \& Dairy Sci. 1(2): 69-72.

Cruickshank, R.; Duguid, J.P.; Marmion, B.P.; Mackie, T.J. and Swain, R.H.A. (1973): Medical Microbiology: a guide to the laboratory diagnosis and control of infection. $12^{\text {th }}$ Ed., E. and S. Churchill Livingstone Ltd., Edinburgh and London.

Donagh, P.B. and William, J.M. (2005): Interdependence and distribution of subclinical mastitis and intra-mammary infection among udder quarters in dairy cattle. Preventive Vet. Med. (75): 81-91.

Duguma, A.; Tolosa, T. and Yohannes, A. (2014): Prevalence of clinical and sub-clinical mastitis on cross bred dairy cows at Holleta Agricultural Research Center, Central Ethiopia. J. Vet. Med. Anim. Health. (1): 1317.

El-Kholy, A.M.; Hassan, G.M.; Zeinhom, M.M.A. and El-Klawy, M.A.A.M. (2018): Detection of subclinical mastitis in a dairy farm in Beni Suef city, Egypt. Assiut Vet. Med. J. 64 (157):18-24.

El-Sokkary, A.M. and Hassan, H.A. (1950): Lactose and chloride contents of Egyptian cows' and Buffaloes' Milks. J. Analyst. 75: 143-146.

Enany, M.E.; EL-Attar A.A.; Khafagy, A.A.R. and ELGammal, A.M. (2007): Bacterial and mycotic causes of subclinical bovine mastitis. SCVMJ, XII (2): 107-114.

Greiner, M.; Pfeiffer, D. and Smith, R.D. (2000): Principles and practical application of the receiver-operating characteristics analysis for diagnostic tests. Prev. Vet. Med. 45: 23-41.

Gupta, A.; Chopde, D.; Jadhav, J.B.; Tamboli, S. and Shinde, B. (2017): Comparative techniques for detecting mastitis in bovine milk samples.
Innovative Journal of Medical Sciences, 5: 2124.

Halasa, T.; Nielen, M. and De Roos, A. (2009): Production loss due to new subclinical mastitis in Dutch dairy cows estimated with a test-day model. J. Dairy Sci., 92: 599-606.

Hotis, R.P. and Miller, W.T. (1936): A Simple test for detecting mastitis Streptococci in milk. Circular 400 United States Department of Agriculture.

Hussain, R.; Javed, M.T.; Khan, A.; Mahmood, F. and Kausar, R. (2012): Mastitis and associated histo-pathological consequences in the context of udder morphology. Int. J. Agric. Biol., 14: 947-952.

Hussain, R.; Khan, A.; Javed, M.T. and Ali, F. (2013): Morphometric and pathological studies on mammary gland of slaughtered Nili-Ravi buffaloes. Pak. J. Agric. Sci., 50: 123-130

Hussein, S.A. (2012): Prevalence and bacterial etiology of subclinical mastitis in dairy cows in Al Sulaimaniyah District. Kufa J. Vet. Med. Sci. (3): 190-203.

Iqbal, M.; Khan, M.A.; Daraz, B. and Siddique, U. (2004): Bacteriology of mastitic milk and in vitro antibiogram of the isolates. Pakistan Vet. J. 24(4): 161-164.

Kabir, M.H.; Ershaduzzaman, M.; Giasuddin, M.; Islam M.R.; Nazir, K.H.M.N.H.; Islam, M.S.; Karim, M.R.; Rahman, M.H. and Ali, M.Y. (2017): Prevalence and identification of subclinical mastitis in cows at BLRI Regional Station, Sirajganj, Bangladesh. Journal of Advanced Veterinary and Animal Research, 4(3): 295-300.

Kamal, R.M.; Bayoumi, M.A. and Abd El Aal, S.F.A. (2014): Correlation between some direct and indirect tests for screen detection of subclinical mastitis. International Food Research Journal, 21(3): 1249-1254.

Kasikci, G.; Cetin, O.; Bingol, E.B. and Gunduz, M.C. (2012): Relations between electrical conductivity, somatic cell count, California mastitis test and some quality parameters in the diagnosis of subclinical mastitis in dairy cows. Turk. J. Vet. Anim. Sci. 36(1): 49-55.

Klaas, I.C. (2000): Untersuchungen zum Auftreten von Mastitiden und zur Tiergesundheit in 15 Milchviehbetrieben Schleswig-Holsteins. Dissertation, Free University-Berlin.

Klastrup, O. and Schmidt, M.P. (1974): Nordic recommendations concerning mastitis control of quarter samples. Nord. Vet. Med., 26: 197204.

Koestler, G.A. (1920): Mitt. AusdemGeb. Lebensmie. Untersuch. U. Hyg., 11, 154.

Konwar, D.; Barman, K. and Singh, Y. (2009): Management, A key to prevention of mastitis. Indian Dairyman, 61: 29-33. 
Lancelot, R.; Faye, B. and Lesco-urret, F. (1997): Factors affecting the distribution of clinical mastitis among udder quarters in French dairy cows, Vet. Res., 28: 45-53.

Mahon, C.R. and Manuselis, J.G. (1995): Textbook of diagnostics microbiology, Philadelphia, W.B. Saunders Company.

Morsi, N.M.; Saleh, Y.; El Ghazzar, H. and Hanafi, A. (2000): Effect of mastitis on milk fat content. Pakistan Journal of Biological Science, 3(2): 196-200.

Mureithi, D.K. and Njuguna, M.N. (2016): Prevalence of subclinical mastitis and associated risk factors in dairy farms in urban and peri-urban areas of Thika Sub County, Kenya. Livest. Res. Rural Dev. 28(2): 13.

Oliver, S.; González, R.; Hogan, J.; Jayarao, B. and Owens, W. (2004): Microbiological procedures for the diagnosis of bovine udder infection and determination of milk quality, 4th Ed, National Mastitis Council, Verona, WI, USA: 1-28.

Payne, J.A. and Wilson, R.A. (1999): An introduction to animal husbandry in the tropics. Black well Sci., Ames, pp. 63-178

Philpot, W.N. (1984): Mastitis and management. $2^{\text {nd }}$ ed. Babson Bros. Comp. 21005 York Road USA.

Quinn, P.J.; Markey, B.K.; Carter, M.E.; Donnelly, W.J.C.; Leonard, F.C. and Maguire. (2002): Veterinary microbiology and microbial diseases. $1^{\text {st }}$ Blackwell Science $1^{\text {st }}$ ed. Roest, H.I

Radostitis, O.M.; Gay, C.C.; Hinchcliff, K.W. and Constable, P.D. (2007): A text book of the diseases of cattle, sheep, pigs, goats and horses. Vet. Med. $10^{\text {th }}$ Ed.

Saidi, R.; Khelef, D. and Kaidi, R. (2013): Subclinical mastitis in cattle in Algeria: Frequency of occurrence and bacteriological isolates. Journal of the South African Vet. Association, 84(1):929-934.

Saloniemi, H. (1995): Use of Somatic Cell Count in udder health work. In: The bovine udder and mastitis. Editors: Sandholm, M., Honkanen, T., Honkanen-Buzalski, T., Kaartinen, L. and Pyorala. S. Iyvaskyla, Finland: Gummerus Kirjapaino Oy. p.105-110.

Sanders, G.P. (1939): The determination of chloride in milk. J. Dairy Sci., 22(10): 841-852.
Sanotharan, N.; Pagthinathan, M. and Nafees, M.S.M. (2016): Prevalence of bovine subclinical mastitis and its association with bacteria and risk factors in milking cows of batticaloa district in Sri Lanka. International, J. of Sci., Research and Innovative Technology, 3: $137-150$

Schalm, O.W. (1977): Pathologic changes in the milk and udder of cows with mastitis. JAVMA, 170:1137-1140.

Schalm, O.W.; Carroll, E.J. and Jain, N.C. (1971): Bovine mastitis. Lea and Febiger, Philadelphia, USA, 132- 360 pp.

Shahid, M.; Saber, N.; Ahmed, I.; Khan, R.W.; Irshad, M.; Rizwan, M. and Ahmed, S. (2011): Diagnosis of subclinical mastitis in bovine using conventional methods and electronic detector. ARPN Journal of Agricultural and Biological Science, 6(11): 18-22.

Swami, S.V.; Patil, R.A. and Gadekar, S.D. (2017): Studies on prevalence of subclinical mastitis in dairy animals. Journal of Entomology and Zoology Studies; 5(4): 1297-1300.

Tanwar, R.K.; Vyas, S.K.; Fakhruddin and Singh, A.P. (2001): Comparative efficiency of various diagnosis tests in diagnosis of subclinical mastitis in Rathi cows. Proc. of Indian Vet. Congress. No.2, 161-163.

Thirapatsakun, T. (1999): Mastitis management in Smallholder dairying in the tropics. In: Hunt and Chantalakhana (eds). International Livestock Research Institute, Kenya, Nairobi. Pp. 299-339.

Unal, N. and Yildirim, M. (2010): Antibiotic resistance profiles of Staphylococci species isolated from milk, teat skins and noses mucous of cows. Kafkas Univ. Vet. Fak. Derg. 16: 389-396.

Wahba, Nahed, M.; Ali, M.M. and Abdel-Hafeez, M.M. (2005): Microbiological profile of subclinical mastitic cow milk and its correlation with field tests and somatic cell count. Assiut Vet. Med. J. 51(104):62-75.

Zahid, I.A. (2004): Studies on comparative incidence of subclinical and clinical mastitis and vitro antibiotic susceptibility of isolates from Holstein -Friesian and Jersey cows and buffaloes. Pakistan Vet. J. 24(2): 76-81. 


\section{الكثف عن إلتهاب الضرع الخفي في لبن الأبقار الحلاب في مدينة سوهاج ، مصر \\ نسرين بكر ، إيبان مختار شاكر ، محمد سبل}

E-mail: milk_121970@yahoo.com_Assiut University web-site: www.aun.edu.eg

تم تجميع عدد . ا عينة لبن من كل ربع من أرباع 0ب بقرة حلابة بضرع سليم ظاهريا من مدينة سوهاج، مصر، وذللك لفحصهم

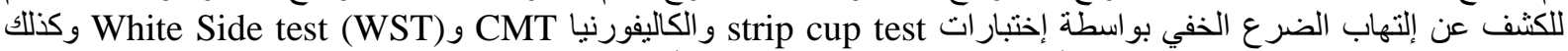

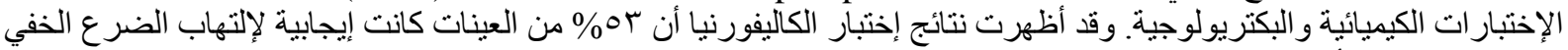

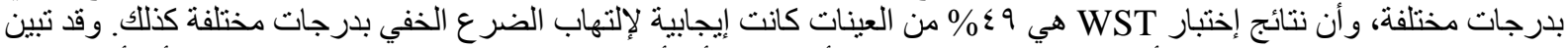

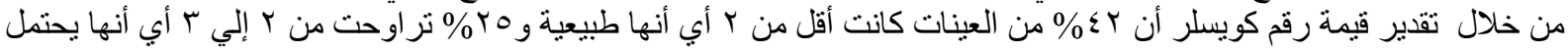

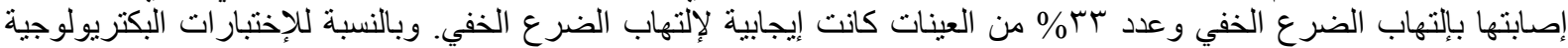

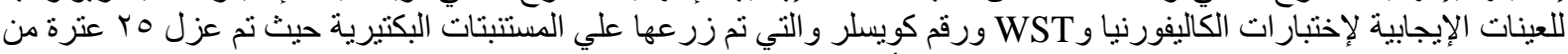

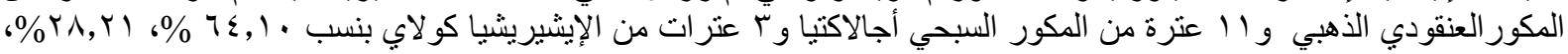

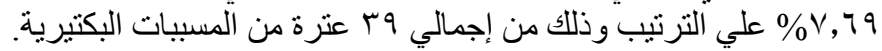

الكلمات الكاثفة: إلتهاب الضرع الخفي، إختبار الكاليفورنيا، إختبار WST، رقم كويسلر. 